\title{
What's on the label is not necessarily in the jar
}

Henry Asajiro Kemp

January 2009.

\section{A tribute to Prof \& Taisa}

Brown hair,

Brown eyes,

Brown face,

What are you doing in this place?

Blond hair,

Blue eyes,

Pale face,

He belongs to a different race!

A healer, a philosopher, a poet, a writer with a social conscience.

"Ahhh, what's on the label's not necessarily in the jar."

\section{A memory to Asajiro Noda}

Four foot something,

A man who lost his country,

Never to be seen again,

English, German and Maori he communicates fluently,

With permission from the King he begins a new life story,

World War II and imprisoned for his ethnicity,

His youngest daughter has four siblings,

The oldest son has nine,

The last is an enigma.

"Ahhh, what's on the label's not necessarily in the jar."

\section{Ode to MUA}

He's a New Zealand born Samoan

He wears three quarter pants, floral shirt, and shaved head

A poet, an academic, a community leader,

Who wears a minister's collar.

He sacrifices for his friends.

Youth worker, peace maker, song weaver, a social conscious true.

"Ahhh, what's on the label's not necessarily in the jar."

\section{To my friends and Mr Lee}

Red and blue lights flashing,

Four black faces in a car,

Academics they say they are.

Unbelieved by police, 
But students none the less.

"Ahhh, what's on the label's not necessarily in the jar."

\section{To a friend}

A Ngati Kahungunu Waihine,

Blue eyes and pretty face,

You hold a special place,

KFC, Paddle Ducks, boil ups with our friends,

Mr Lee transports us here and there,

We share our work assignments too,

Tautoko whanau we get an A.

"Ahhh, what's on the label's not necessarily in the jar."

\section{Ode to Leland}

Jeans,

T shirt,

Beanie, dark shades and gumboots.

A Maori with a working class story,

Here, he represents his whanau well,

A doctorate to change that history,

A lecturer at the university.

A heart worker, seer too.

"Ahhh, what's on the label's not necessarily in the jar."

\section{Ode to Hinemoa}

Gruff, hard exterior,

Tells it like it is,

Pulls no punches and lets you know what she thinks,

Lived a life of hardship bequeathed to her by fate,

Finds a photo of an old pakeha lady in the rubbish on the street,

Gives her pride of place on the mantelpiece,

Mrs Magee is the Queen.

I REMEMBER YOU HINEMOA

"Ahhh, what's on the label's not necessarily in the jar."

\section{To someone I knew}

Blond hair, blue eyes,

I don't want to be this person society expects of me,

I feel like someone else,

Maybe Japanese,

It's hard to love somebody,

Who is unsure of what they want,

"You're going to end up a lonely old lady with a cat."

"Ahhh, what's on the label's not necessarily in the jar."

\section{Ode to whanau}

Four families,

Biological, 
Adopted,

Spiritual,

And friends,

They've all contributed to who I am,

And when they define me,

And you ask them who I am,

You will hear them all say.

"Ahhh, what's on the label's not necessarily in the jar."

\section{We all have layers}

Peel back the layers,

Remove the facade,

Strip away the fabrication that we want others to think we are,

Multi faceted persona adopted through experience,

Walls to protect our emotions can make us prisoners,

After all that's said and done, we wonder who we are.

Dig deep no shadows of regret to hide behind.

"Ahhh, what's on the label's not necessarily in the jar."

\section{Moko}

He sits alone on the table surrounded by everyone's stuff,

He looks a forlorn brown figure,

With a story on his face,

Do I pick him up and take him?

Or do I simply pass him by?

Do I leave him with his golf clubs, picture frames, and English china?

I move on to the next table,

Again he catches my eye,

A lonely brown face in a desolate place that nobody wants to buy,

I walk up to the counter and give $\$ 5$ bucks to the guy,

He gives $\$ 2.50$ change,

I didn't pass him by.

"Ahhh, what's on the label's not necessarily in the jar."

\section{An ode to Pa Shoe from mates}

Black leathers,

Dreadlocks,

Lion Red,

The wiff of gunja,

Headhighs, late tackles, ah!

That's grassroots rugby league.

Oblivious to your thoughts,

Sorry about that bro,

Out of place, nah can't be,

You're brown like all of us.

"Ahhh, what's on the label's not necessarily in the jar".. 
Whangai out with good intentions, grandmother thought it best.

Chinese, Japanese, Fijian, mistaken identity,

Sailing on Sydney Harbour, whuzz up wit dat bro,

Buying not stealing lunches,

Dog whisperer, no not you,

A listening ear, a friend indeed,

"What's on the label's not necessarily in the jar?"

A he-man blessed with she-man skills

And the women run for cover

Aromas and soul food delicacies

A platter for kings and queens

Is it right that roles are reversed in the kitchen?

Fingers play fox trot over nerves so dead

Cries restore lost mana and limbs revive

A master's hand that heals.

HENRY BRO . . . A social worker too.

"Ahhh, what's on the label's not necessarily in the jar." 